\title{
Az endokrin orbitopathia differenciáldiagnosztikája
}

\author{
Erdei Annamária dr. ${ }^{1}$ - Steiber Zita dr. ${ }^{2}$ - Gazdag Annamária dr. ${ }^{1}$ \\ Bodor Miklós dr. ${ }^{1,7}$. Berta Eszter dr., ${ }^{1,7}$. Szász Róbert dr. ${ }^{3}$ \\ Szántó Antónia dr. ${ }^{4}$. Ujhelyi Bernadett dr. ${ }^{2}$ - Barna Sándor dr. ${ }^{5}$ \\ Berényi Ervin dr. ${ }^{6}$ - Nagy V. Endre dr. ${ }^{1}$ \\ Debreceni Egyetem, Általános Orvostudományi Kar, ${ }^{1 B}$ Belgyógyászati Intézet, Endokrinológia Tanszék, \\ ${ }^{2}$ Szemészeti Klinika, ${ }^{3}$ Belgyógyászati Intézet, Hematológia Tanszék, \\ ${ }^{4}$ Belgyógyászati Intézet, Immunológia Tanszék, ${ }^{5}$ Nukleáris Medicina Tanszék, ${ }^{6}$ Radiológiai Intézet, Debrecen \\ ${ }^{7}$ Debreceni Egyetem, Gyógyszertudományi Kar, Klinikai Farmakológiai Tanszék, Debrecen
}

\begin{abstract}
Az endokrin orbitopathia a leggyakoribb exophthalmust okozó betegség, a Graves-kór extrathyreoidalis manifesztációja. Mivel a kórkép az esetek legnagyobb részében a hyperthyreosis típusos tüneteivel együtt jelentkezik, általában nem jelent gondot a betegség felismerése. A szerzők az endokrin orbitopathia differenciáldiagnosztikájában szereplő kórképeket foglalják össze a rendelkezésre álló irodalmi adatok áttekintése mellett saját 4 esetük bemutatásával. Kiemelik, hogy endokrin orbitopathiához hasonló tünetek - bár általában könnyen felismerhető a betegség - más kórképekben is jelentkezhetnek. Az endokrin orbitopathiával foglalkozó szakembereknek ismerni kell a hasonló tünetekkel járó kórállapotokat, hogy a beteg a megfelelő kezelést időben megkapja. Orv. Hetil., 2016, 157(8), 310-315.
\end{abstract}

Kulcsszavak: endokrin orbitopathia, idiopathiás inflammatorikus orbitopathia, occularis lymphoma, $\operatorname{IgG}_{4}$-asszociált betegség, myasthenia gravis

\section{Differential diagnosis of Graves' orbitopathy}

\section{Case report}

Graves' orbitopathy is the extrathyroidal manifestation of Graves' disease, which is the most common cause of exophthalmos. As eye symptoms usually coincide with the development of thyrotoxicosis, the diagnosis of the disease is rarely difficult. The aim of the authors was to summarize the differential diagnosis of Graves' orbitopathy based on literature review and presentation of their own four problematic cases on this topic. They conclude that symptoms similar to endocrine orbitopathy are present in other disorders. Endocrinologists need to be aware of these other conditions to avoid treatment failures.

Keywords: Graves' orbitopathy, idiopathic inflammatory orbitopathy, ocular lymphoma, IgG4-related disease, myasthenia gravis

Erdei, A., Steiber, Z., Gazdag, A., Bodor, M., Berta, E., Szász, R., Szántó, A., Ujhelyi, B., Barna, S., Berényi, E., Nagy, $V$. E. [Differential diagnosis of Graves' orbitopathy. Case report]. Orv. Hetil., 2016, 157(8), 310-315.

(Beérkezett: 2015. december 19.; elfogadva: 2016. január 7.)

\section{Rövidítések}

CLL = krónikus lymphoid leukaemia; CT = komputertomográfia; $\mathrm{EOP}=$ endokrin orbitopathia; $\mathrm{IgG}_{4}=$ immunglobulin $\mathrm{G}_{4} ; \mathrm{ISZB}=$ ischaemiás szívbetegség; MALT $=$ mucosa associated lymphoid tissue; MRI = magnetic resonance imaging; SPECT $=$ single photon emission computer tomograph; TRAb $=$ TSH-receptor-ellenes antitest; TSH = thyreoideastimuláló hormon
Az endokrin orbitopathia (EOP) a Graves-kór leggyakoribb extrathyreoidalis szövődménye és a leggyakoribb exophthalmust okozó kórkép. A szemtünetek az esetek döntő részében (körülbelül 80\%-ában) a pajzsmirigy-túlmúködés típusos tüneteivel együtt jelentkeznek, így a betegség felismerése általában nem jelent gondot. Az endokrin orbitopathia esetén az autoimmun gyulladás az 
orbita minden struktúráját érintheti, egyénenként eltér, hogy a kötőszövet vagy a külső szemmozgató izmok érintettsége a kifejezettebb. A „legismertebb” tünet az exophthalmus (más néven: proptosis, protrusio bulbi), amely a retrobulbaris térben felszaporodó kötőszövet és oedema miatt jön létre. További következménye a szemhéjak retrakciója, szemhéjzárási képtelenség, súlyos esetben látást veszélyeztető corneafekély, valamint nervusopticus-kompresszió lehet. A conjunctiva és a sclera érintettsége conjunctivitis, conjunctivalis chemosis és episcleritis formájában jelentkezhet, utóbbi szerencsére ritka. A külső szemmozgató izmok károsodott múködése kettős látást okozhat. Az endokrin orbitopathia diagnosztikájához a pajzsmirigy hormonszintjeinek és a TSH-receptor-ellenes antitest szintjének mérése, részletes szemészeti vizsgálat, valamint - a betegség aktivitásának megítéléséhez - képalkotó vizsgálatok (orbita-MR, orbita-SPECT) szükségesek. A kezelés alapját a pajzsmirigyhormon-státusz rendezése, a dohányzás abbahagyása, lokális szemészeti készítmények alkalmazása, aktív szakban immunszuppresszív kezelés (kortikoszteroid és retrobulbaris irradiáció), majd inaktív stádiumban korrekciós szemmútét jelenti, emellett vannak adatok a biológiai terápiák hatékonyságáról is [1-3].

A második leggyakoribb orbitainfiltrációval járó betegségcsoportot az orbita lymphoproliferativ kórképei képezik, amelyek az orbita malignus elváltozásai közül a leggyakoribbak. A lymphomák körülbelül 1\%-ában van ocularis érintettség, és az extranodalis lymphomák 8\%-a érinti a szemet. A szövettani típusok közül a MALT-lymphoma (marginális zóna), follicularis lymphoma, diffúz nagy B-sejtes lymphoma, plasmacytoma, köpenysejtes lymphoma és a hairy cell leukaemia fordul elő. Idős életkor és férfi dominancia jellemző. A diagnózis felállításához képalkotó módszerek (orbita-CT és/vagy -MR) és szövettani vizsgálat szükséges. A kezelés kemoterápia és/vagy irradiáció $[4,5]$.

A harmadik leggyakrabban előforduló, orbitát érintő betegség az úgynevezett idiopathiás inflammatorikus orbitopathia vagy más néven pseudotumor orbitae, amelyet először 1905-ben írt le Birch-Hirschfield. Tünettana az endokrin orbitopathiához hasonló, de pajzsmirigybetegség fennállása nem igazolható. A betegség etiológiája pontosan nem ismert, különböző infektív ágensek (Streptococcus pharyngitis, felső légúti vírusinfekció, Borrelia burgdorferi) és autoimmun betegségek (rheumathoid arthritis, szisztémás lupus erythematosus, Crohnbetegség) merültek fel, mint kiváltó tényezők. A diagnózis felállításában képalkotó vizsgálatok segíthetnek (CT, MR), de a szövettani vizsgálat elvégzése minden esetben indokolt, elsősorban malignitás kizárása érdekében. Orbita pseudotumor esetén a hisztológiai kép benignus lymphoid hyperplasiát, gyulladásos sejtes infiltrációt mutat nekrotizáló vasculitissel. A kezelés szisztémás kortikoszteroidterápia, szülkség esetén irradiációval kiegészítve, illetve ezek hatástalansága esetén egyéb immunszuppresszív kezelés is szóba jöhet, valamint vannak adatok a biológiai terápiák hatásosságáról is [6-10].

Az IgG $_{4}$-asszociált betegség egy közelmúltban „nevesített" kórkép, amelyet változatos szervi manifesztáció, fizikális és képalkotó vizsgálatokkal térfoglalásnak imponáló megjelenés jellemez. Leginkább az exokrin mirigyek érintettek, így a szem esetében a könnymirigyek, de az orbita minden része involvált lehet. A diagnózis felállításában, a jellegzetes klinikai tünetek mellett, az emelkedett $\mathrm{IgG}_{4}$-szint segít, de a szövettani vizsgálat minden esetben elengedhetetlen, amely az érintett szervben $\mathrm{IgG}_{4}$-pozitív plazmasejt-infiltrációt mutat. Az első választandó terápia az orális kortikoszteroid, amelyre általában gyors és látványos javulás észlelhető, míg súlyosabb esetekben biológiai kezelésre (rituximab) lehet szükség [11-14].

A fentiek mellett egyéb betegségek is - jóval ritkábban - járhatnak exophthalmussal és utánozhatnak endokrin orbitopathiát. Az orbita egyéb (nem lymphoproliferativ) benignus és malignus tumorai szerencsére rendkívül ritkák, általában sebészi kezelést igényelnek [15-18]. A Cushing-szindrómás betegek 30-45\%-ában is észlelhető exophthalmus, amely a retroorbitalis zsír felszaporodása következtében jön létre. A jelenség pontos oka nem ismert, de felmerül fokozott glükokortikoidreceptor-denzitás, a lipolysis zavara és fokozott lipoproteinlipáz-aktivitás is [19-21]. Extrém obesitasban is - valószínúleg a Cushing-szindrómához hasonló okokból - jelen lehet proptosis.

A myasthenia gravis a Graves-kórhoz hasonlóan autoimmun betegség, amelynek fó tünete az izomgyengeség. Amennyiben a betegség izoláltan a szemizmokra lokalizálódik, ocularis myasthenia gravisról beszélünk, amelynek tünete a ptosis mellett diplopia lehet. A diagnózis felállítása immunszerológiai és provokációs tesztekkel történik. A patomechanizmusból adódóan a kezelés immunszuppresszív terápiát jelent elsősorban, súlyos esetben plazmaferézis vagy thymectomia is szükségessé válhat. Azon túl, hogy az ocularis myasthenia gravis tünetei endokrin orbitopathiát utánozhatnak, a két betegség társulása is előfordulhat. Epidemiológiai tanulmányok alapján a myasthenia gravisban szenvedő betegek 5-10\%ánál autoimmun pajzsmirigybetegség kialakulásával is számolni kell. Az autoimmun pajzsmirigybetegség esetén $0,2 \%$ a myasthenia gravis társulásának esélye. Az autoimmun betegségekhez ocularis myasthenia gyakrabban társul, mint a generalizált forma. A hyperthyreosis fokozza az ocularis myasthenia tüneteit, ezért is fontos a két betegség együttes előfordulása esetén a folyamatos euthyreoid állapot biztosítása [22-24].

Dolgozatunk célja az endokrin orbitopathia differenciáldiagnosztikájának bemutatása saját eseteinken keresztül. 


\section{Esetismertetések}

\section{Elsö eset - Idös nöbeteg pajzsmirigy- túlmüködéssel és féloldali exophthalmussal}

Az idős, 71 éves nőbeteget hematológus kolléga utalta az endokrin rendelésre hyperthyreosis és jobb oldali exophthalmus miatt Graves-kór gyanújával. A beteg krónikus lymphoid leukaemia (B-CLL) miatt 3 éve állt gondozás alatt, kemoterápiát is kapott, 2 éve remisszióban volt. Két hónappal korábban kezdődtek szemtünetei: jobb oldali proptosis és ptosis alakult ki, valamint a felső szemhéj alatt tapintható duzzanatot észlelt (1. táblázat). A laborleletek igazolták a pajzsmirigy-túlmúködést, TSH-receptor-antitest- (TRAb-) negativitás mellett. Fizikális vizsgálattal a pajzsmirigy jobb lebenyében nagyméretű göböt észleltünk, amely ultrahanggal $4 \mathrm{~cm}$-es volt és izotópvizsgálattal toxicus adenomának bizonyult. A fenti leletek és a jobb szemhéj ptosisa EOP ellen szóltak, ezért orbita-MR készült, amely lymphoproliferativ betegségre jellegzetes képet mutatott (1. ábra). Szövettani vizsgálat CLL-t igazolt, ezért a szövettani eredmény alapján ismételt kemoterápia indult, amely nem hozott megfelelő javulást. A hematológus szövettani revíziót kért, mivel a CLL ocularis manifesztációját még a szövettani lelet birtokában sem tartotta valószínűnek. Az ismételt hisztológiai kiértékelés során köpenysejtes lymphomát véleményeztek és ugyanezt találták 3 évvel ezelőtti nyirokcsomóminta szövettani revíziója során is. Ezt követően irradiációt kapott, amely jelentős javulást hozott. A hyperthyreosis miatt radiojódkezelést adtunk, a beteg euthyreoiddá vált.

\section{Második eset - Fiatal férfi beteg kifejezett exophthalmussal pajzsmirigybetegség nélkül}

A 37 éves férfi beteg két hete tartó szempanaszokkal („piros”, fájdalmas szemekkel) jelentkezett a Szemészeti Klinikán. Korábban nagyobb betegsége nem volt. A szemészeti vizsgálat során mindkét szemen kifejezett chemosis, exophthalmus (Hertel 24-26/110 mm), szemmozgás-korlátozottság és emelkedett szemnyomás volt észlelhető (1. táblázat). Az orbita-MR megvastagodott szemmozgató izmokat és megnyúlt T2 relaxációs időket mutatott (1. ábra). A tünetek, az MR-kép és a családi anamnézis (a beteg lánytestvérénél ismert Graves-kór és társuló EOP) alapján felmerült endokrin orbitopathia lehetősége, ezért endokrinológiai véleményezést kértek. A pajzsmirigyhormonszintek a normáltartományban voltak, TRAb negatív volt. Parenteralis methylprednisolonkezelés mellett (1,5 g összdózis) a szemek státusza nem javult, visusa romlott (jobb szem 0,7 , bal szem 0,8 ), ezért retrobulbaris irradiációt kezdtünk. A besugárzás után visusa normalizálódott, exophthalmusa megszünt és szemnyomásértékei is a normál- tartományba kerültek (1. táblázat). Öt évvel a tünetek megjelenése után panaszmentes, pajzsmirigybetegség, egyéb autoimmun betegség továbbra sem igazolódott. A fentiek alapján idiopathiás inflammatorikus orbitopathiát véleményeztünk.

\section{Harmadik eset - Fiatal nőbeteg szülés utáni exophthalmussal és szürke zónában lévo" TSH-receptor-ellenes antitest szinttel}

A 25 éves nőbeteget szülés után 10 héttel a szemészeti ambulanciáról utalták az endokrinológiai szakrendelésre endokrin orbitopathia gyanújával. Kórelőzményében 10 éves folyamatos bőrgyógyászati gondozás ismeretlen etiológiájú, elsősorban az alsó végtagok bőrére lokalizálódó „kiütések” miatt, valamint ugyancsak 10 éve ismert asthma bronchiale szerepel. Egy alkalommal, öt éve dacryoadenitis miatt is kezelték, panaszai kortikoszteroidtartalmú szemcsepp alkalmazása mellett megszúntek. Már a terhesség alatt szem környéki oedema jelentkezett, amelyet a terhesség következményének tartottak. Panasza a szülés után fokozódott, valamint a szemhéjak vörössége és szem mögötti fájdalom is kialakult. Szemészeti vizsgálattal a Hertel-érték 24-21/105 mm volt, kifejezett periorbitalis oedema és a jobb felső szemhéj alatt gyulladásos szövetszaporulat volt észlelhető (1. táblázat). Az arc bal oldalán egy tapintható terimét is panaszolt, amely ultrahanggal a parotis előrenyúló állományának bizonyult. Orbita-MR a szemhéjak oedemáját írta le, emellett a lateralis és felső egyenes szemmozgató izmok szimmetrikusan szélesebbek voltak (1. ábra). Pajzsmirigymúködés-zavar, TRAb-pozitivitás nem igazolódott. Később a követési időszak alatt két alkalommal a TRAb a szürke zónában volt, de pajzsmirigyhormoneltérés nem alakult ki. Az anamnesztikus adatok és az elkészült vizsgálatok alapján felmerült $\mathrm{IgG}_{4}$-asszociált orbitopathia lehetősége. A jelentősen emelkedett $\operatorname{IgG}_{4}$ szint $(9,4 \mathrm{~g} / 1$, normáltartomány: 0,08-1,4 g/l) és a könnymirigyből vett minta szövettani lelete megerősítette a feltételezett diagnózist. Per os kortikoszteroidkezelést kezdtünk (napi 16 mg methylprednisolon), és néhány nap alatt - az irodalmi adatoknak megfelelően - drámai javulás következett be a szemek állapotában, emellett az évek óta perzisztáló bőrtünetek is megszúntek. Betegünk esetében az $\mathrm{IgG}_{4}$-asszociált betegség szervi manifesztációi közül a parotis és a bőrérintettség mellett a tüdőérintettség felmerült, a beteg azonban a további szövettani vizsgálatokba nem egyezett bele.

\section{Negyedik eset - Középkorú férfi beteg pajzsmirigy-túlmüködéssel és kettôs látással}

A 48 éves férfi beteg hyperthyreosis típusos tüneteivel (palpitatio, melegintolerancia, fogyás) jelentkezett az endokrin rendelésen, emellett fél éve fennálló kettős látást panaszolt. Kórelőzményéből szívizominfarktus, corona- 


\begin{tabular}{|c|c|c|c|}
\hline Betegség & $\begin{array}{l}\text { A szemek állapota kezelés előtt és } \\
\text { után }\end{array}$ & Életkor, nem & A diagnózis alappillérei \\
\hline Endokrin orbitopathia & & Fiatalabb életkor, női dominancia & $\begin{array}{l}\text { Pajzsmirigyhormonszint-eltérés, } \\
\text { TRAb-pozitivitás, szemészeti } \\
\text { vizsgálat, orbita-SPECT és/vagy } \\
\text { orbita-MRI }\end{array}$ \\
\hline $\begin{array}{l}\text { Ocularis lymphoproliferativ } \\
\text { kórképek }\end{array}$ & Első eset & Idősebb életkor, férfi dominancia & $\begin{array}{l}\text { Orbita-CT, szövettan, } \\
\text { vérképeltérések }\end{array}$ \\
\hline $\begin{array}{l}\text { Idiopathiás inflammatorikus } \\
\text { orbitopathia }\end{array}$ & Második eset & Nem jellemző & $\begin{array}{l}\text { Klinikai tünetek, orbita-MRI és / } \\
\text { vagy -CT, szövettan a malignitás } \\
\text { kizárására }\end{array}$ \\
\hline $\mathrm{IgG}_{4}$-orbitopathia & Harmadik eset & Idősebb életkor, férfi dominancia & $\begin{array}{l}\text { Klinikai tünetek, egyéb szervi } \\
\text { manifesztációk megléte, } \\
\text { emelkedett } \mathrm{IgG}_{4} \text {-szint, szövettan }\end{array}$ \\
\hline \multirow[t]{2}{*}{ Ocularis myasthenia gravis } & Negyedik eset & $\begin{array}{l}\text { Fiatalabb (30-40 év) nók, } \\
\text { idősebb (60-80 év) férfiak }\end{array}$ & $\begin{array}{l}\text { Neurológiai vizsgálat, repetitív } \\
\text { válasz, mellkas-CT thymoma } \\
\text { keresése céljából }\end{array}$ \\
\hline & A kezelés nem eredményezett vá & zást & \\
\hline
\end{tabular}

ria-bypassmútét, ISZB miatti kardiológiai gondozás emelhető ki. Fizikális vizsgálat során mérsékelten nagyobb, tapintással göbmentes pajzsmirigyet, enyhe jobb oldali túlsúlyú exophthalmust észleltünk és a beteg oldalra tekintéskor mindkét irányban kettős képet jelzett (1. táblázat). A panaszok és a fizikális vizsgálat alapján hyperthyreosist okozó Graves-kór és társuló endokrin orbitopathia volt a feltételezett diagnózis. Laborvizsgálat igazolta a pajzsmirigy-túlmúködést, a TSH-receptor- ellenes antitest meghatározása viszont negatív lett. Szemészeti vizsgálat során kétoldali musculus rectus internus gyengeséget véleményeztek, a clinical activity score mindkét oldalon 4 volt. Mindezen eltérések endokrin orbitopathiára utalhattak volna. Pajzsmirigyultrahang és $\mathrm{Tc}^{99 \mathrm{~m}}$-gamma-kamerás vizsgálat alapján bal oldali toxikus adenoma igazolódott. A beteg által panaszolt kettős látás miatt - a TRAb-negativitás és a toxikus adenoma ismeretében - neurológiai véleményezést kértünk, ahol felve- 


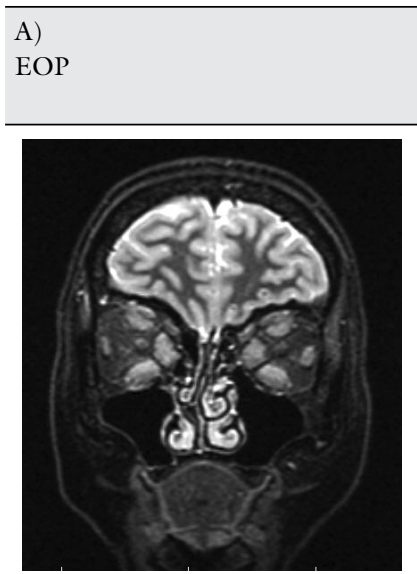

B)

Ocularis lymphoma

(első eset)

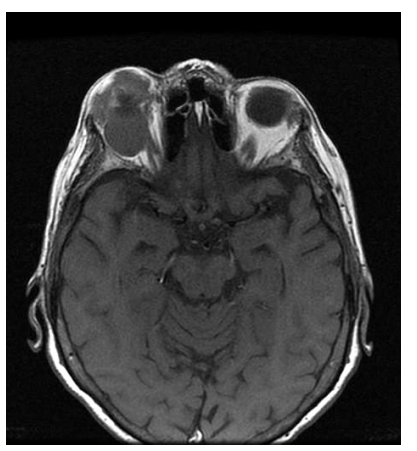

C)

Idiopathiás inflammatorikus orbitopathia (második eset)

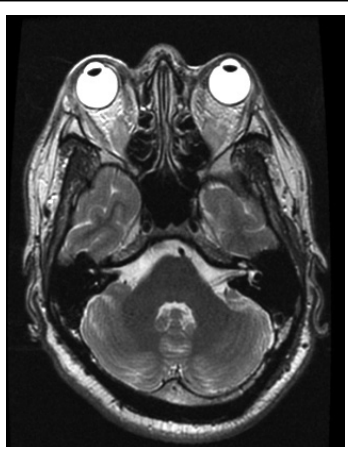

D)

$\mathrm{IgG}_{4}$-orbitopathia (harmadik eset)

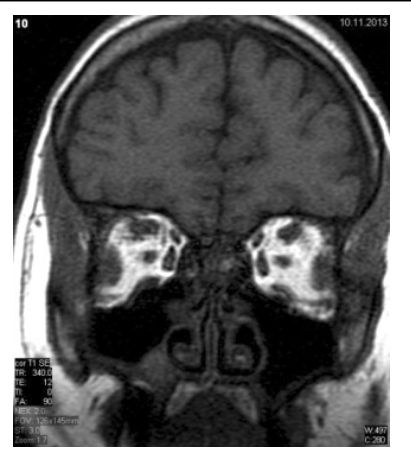

1. ábra

Endokrin orbitopathiát utánzó betegségek orbita-MR-képei

A) Aktív endokrin orbitopathiában szenvedő beteg orbita-MR-képe. A rectus medialis és inferior mindkét orbitában jelentősen megvastagodott, a többi szemmozgató izom érintettsége kisebb mértékü

B) Ocularis lymphomában szenvedő beteg (első eset) orbita-MR-képe. Jobb orbita területi térfoglalás látható, amely lymphoproliferativ betegség manifesztációjának felel meg

C) Idiopathiás inflammatorikus orbitopathiában szenvedő beteg (második eset) orbita-MR-képe. Kifejezett protrusio észlelhető, a rectus medialis és lateralis izmok is vaskosabbak. Az orbita csúcsában mindkét oldalon gyulladásos terület látszik

D) $\mathrm{IgG}_{4}$-orbitopathiában szenvedő beteg (harmadik eset) orbita-MR-képe. A musculus rectus lateralisok mindkét oldalon megvastagodottak

tették myasthenia gravis lehetőségét, amelyet repetitív ingerlési teszt igazolt is. Mellkas-CT-n thymus persistens látszott. Koponya- és orbita-MR is történt, amelyek intracranialis organikus eltérést, retrobulbaris térfoglalást, illetve a szemizmok területén kóros szignált nem mutattak. A beteg a pajzsmirigy túlmúködése miatt - figyelembe véve súlyos koszorúér-betegségét is - radiojódterápiában részesült. A radiojódkezelés óta 7 év telt el, kezelés nélkül euthyreoid. A myasthenia miatt neurológiai gondozás, immunszuppresszív kezelés alatt áll. A thymus persistens mútéti eltávolítása - az ismert szívbetegség miatt - nem történt meg.

\section{Következtetések}

A bemutatott esetek általános tanulságaként elmondható, hogy teljesen típusos anamnézis és status esetén sem nélkülözhető a laboratóriumi és a müszeres vizsgálatok elvégzése az endokrin orbitopathia kezelésének megkezdése előtt. Differenciáldiagnosztikai nehézség esetén a bemutatott betegségek lehetőségére is gondolni kell. Az orbita „infiltrációjával” járó kórképek közül az endokrin orbitopathia a leggyakoribb, de amennyiben EOP-hoz hasonló tünetek észlelése esetén pajzsmirigyhormon-eltérés kizárható és a TSH-receptor-ellenes antitest szintje is negatív, egyéb kórokot kell keresni. Ugyanez a helyzet, ha szemtünet észlelhető, de a pajzsmirigy-túlmúlködést nem Graves-kór okozza. A pontos diagnózis felállításához - a képalkotó vizsgálatok közül - az orbita-MR szerepe emelendő ki (1. ábra), emellett a pontos etiológia tisztázására szövettani mintavétel elvégzése is szükséges lehet (1. táblázat).
Az $\mathrm{IgG}_{4}$-asszociált betegség az utóbbi években került az érdeklődés középpontjába. Egyes szerzők szerint a korábban idiopathiásnak tartott inflammatorikus orbitopathia tulajdonképpen $\mathrm{IgG}_{4}$-orbitopathiának felel meg $[25,26]$. Az általunk bemutatott fiatal férfi (második eset) esetében az orbitopathia jelentkezésekor nem történt $\mathrm{IgG}_{4}$-szint-meghatározás, csak évekkel később, ekkor nem volt emelkedett. Felmerült euthyreoid endokrin orbitopathia lehetősége, amely teljes biztonsággal csak a hosszú távú lefolyás ismeretében zárható majd ki. Az $\mathrm{IgG}_{4}$-orbitopathia diagnosztikus kritériumai szerint mindenképpen szükséges szövettani vizsgálat a diagnózishoz, mivel az $\operatorname{IgG}_{4}$-szint nem minden betegnél magas, valamint más kórképek (sarcoidosis, allergiás kórképek) is emelhetik a szintjét [12]. A fiatal, $\mathrm{IgG}_{4}$-betegségben szenvedő nőbetegnél (harmadik eset) Graves-kór kizárható volt, viszont két alkalommal észleltünk szürke zónában lévő TSH-t, ezért endokrinológiai követését fontosnak tartjuk. A beteg életkora és neme inkább Graves-kórra lenne típusos, mivel az $\mathrm{IgG}_{4}$-betegség inkább idős férfiak betegsége [12]. Az $\mathrm{IgG}_{4}$-betegség társulása Hashimoto- és Riedel-thyreoiditissel jól ismert [27], hasonló a Graves-kór vonatkozásában nem mondható el. Mind az $\mathrm{IgG}_{4}$-orbitopathia, mind az endokrin orbitopathia elsóként választandó kezelése a kortikoszteroid, de az $\mathrm{IgG}_{4}$-orbitopathia esetén az alkalmazott dózisok jóval kisebbek és a kezelésre adott válasz sokkal gyorsabb $[2,11,12]$.

Az endokrin orbitopathia, az idiopathiás inflammatorikus orbitopathia és az $\mathrm{IgG}_{4}$-orbitopathia terápiarefrakter eseteiben is beszámoltak a rituximab kedvező hatásáról $[3,11,14]$. A készítményt eredetileg B-sejtes lymphomák kezelésére alkalmazták és az ocularis érin- 
tettséget mutató lymphoproliferativ kórképek kezelési sémájának is részét képezi. A különböző, orbitát érintő, infiltratív betegségek hasonló tünetei és hasonló kezelési lehetőségei felvetik az orbita viszonyai által meghatározott részben közös patomechanizmus lehetőségét.

Anyagi támogatás: A szerzők anyagi támogatásban nem részesültek.

Szerzői munkamegosztás: E. A.: A kézirat elkészítése, az esetismertetésben szereplő betegek kezelése, a klinikai adatok összegyűjtése. S. Z.: A betegek kezelése, a klinikai adatok összegyújtése, közremúködés a kézirat elkészítésében. G. A., B. M., Sz. R., Sz. A., U. B.: A betegek kezelése, a klinikai adatok összegyüjtése. Berta E.: Közremúködés az irodalmi adatok feldolgozásában. B. S.: A betegek izotópvizsgálatainak elvégzése, a klinikai adatok összegyưjtése. Berényi E.: A betegek radiológiai leleteinek elemzése. N. V. E.: A kézirat elkészítése. A cikk végleges változatát valamennyi szerző elolvasta és jóváhagyta.

Érdekeltségek: A szerzőknek nincsenek érdekeltségeik.

\section{Irodalom}

[1] Bartalena, L., Tanda, M. L.: Clinical practice. Graves' ophthalmopathy. N. Engl. J. Med., 2009, 360(10), 994-1001.

[2] Bartalena, L., Baldeschi, L., Dickinson, A., et al.: Consensus statement of the European Group on Graves' orbitopathy (EUGOGO) on management of GO. Eur. J. Endocrinol., 2008, 158(3), 273-285.

[3] Erdei, A., Gazdag, A., Bodor, M., et al.: Novel treatment opportunities in Graves' orbitopathy. [Új lehetőségek az endokrin orbitopathia kezelésében.] Orv. Hetil., 2014, 155(33), 12951300. [Hungarian]

[4] Eckardt, A. M., Lemound, J., Rana, M., et al.: Orbital lymphoma: diagnostic approach and treatment outcome. World J. Surg. Oncol., 2013, 11(1), 73 .

[5] Vali Khojeini, E., Durham, B. H., Chen, M.: Mantle cell lymphoma and involvement of the orbit and ocular adnexa. Case Rep. Pathol., 2013, 2013, 581856.

[6] Grove, A. S. Jr., Weber, A. L.: Orbital pseudotumor - historical origin and modern relevance. Ophthal. Plast. Reconstr. Surg., 2013, 29(5), 341-346

[7] Li, Y., Lip, G., Chong, V., et al.: Idiopathic orbital inflammation syndrome with retro-orbital involvement: a retrospective study of eight patients. PloS ONE, 2013, 8(2), e57126.

[8] Pakdaman, M., Sepabdari, A. R., Elkhamary, S. M.: Orbital inflammatory disease: Pictorial review and differential diagnosis. World J. Radiol., 2014, 6(4), 106-115.

[9] Yuen, S. J., Rubin, P. A.: Idiopathic orbital inflammation: distribution, clinical features, and treatment outcome. Arch. Ophthalmol., 2003, 121(4), 491-499.
[10] Savino, G., Battendieri, R., Siniscalco, A., et al.: Intraorbital in jection of Rituximab in idiopathic orbital inflammatory syndrome: case reports. Rheumatol. Int., 2015, 35(1), 183-188.

[11] Peter, N. M., Khooshabeh, R., Soilleux, E. J.: IgG4 orbitopathy: unravelling a multisystem diagnostic challenge. Eye, 2012, 26(8), 1150-1151.

[12] Inaba, H., Hayakawa, T., Miyamoto, W., et al.: IgG4-related ocular adnexal disease mimicking thyroid-associated orbitopathy. Intern. Med., 2013, 52(22), 2545-2551.

[13] Glass, L. R., Freitag, S. K.: Management of orbital IgG4-related disease. Curr. Opin. Ophthalmol., 2015, 26(6), 491-497.

[14] Berta, A. I., Agaimy, A., Braun, J. M., et al.: Bilateral orbital IgG4-related disease with systemic and corneal involvement showing an excellent response to steroid and rituximab therapy: report of a case with 11 years follow-up. Orbit, 2015, 34(5), 299-301

[15] Belfquih, H., El Mostarchid, B., Oukabli, M., et al.: Benign chondroid syringoma of the orbit: a rare cause of exophtalmos. Head Face Med., 2012, 8, 8.

[16] Eldesouky, M. A., Elbakary, M. A.: Clinical and imaging characteristics of orbital metastatic lesions among Egyptian patients. Clin. Ophthalmol., 2015, 9, 1683-1687.

[17] Koch, K. R., Matthaei, M., Grau, S. J., et al.: Benign orbital angiomatous tumors with intracranial extension. Eur. J. Med. Res., 2015, 20(1), 63 .

[18] Kabra, R. S., Patel, S. B., Shanbhag, S. S.: Orbital chondroma: a rare mesenchymal tumor of orbit. Indian J. Ophthalmol., 2015, 63(6), 551-554.

[19] Morgan, D. C., Mason, A. S.: Exophthalmos in Cushing's syndrome. Br. Med. J., 1958, 2(5094), 481-483.

[20] Kelly, W.: Exophthalmos in Cushing's syndrome. Clin. Endocrinol., 1996, 45(2), 167-170.

[21] Giugni, A. S., Mani, S., Kannan, S., et al.: Exophthalmos: a forgotten clinical sign of Cushing's syndrome. Case Rep. Endocrinol., 2013, 2013, 205208.

[22] Marinó, M., Ricciardi, R., Pinchera, A., et al.: Mild clinical expression of myasthenia gravis associated with autoimmune thyroid diseases. J. Clin. Endocrinol. Metab., 1997, 82(2), 438443.

[23] Evoli, A., Caliandro, P., Iorio, R., et al.: Poly-autoimmunity in patients with myasthenia gravis: A single-center experience. Autoimmunity, 2015, 48(6), 412-417.

[24] Yeh, J. H., Kuo, H. T., Chen, H. J., et al.: Higher risk of myasthenia gravis in patients with thyroid and allergic diseases: a national population-based study. Medicine, 2015, 94(21), e835.

[25] Wallace, Z. S., Khosroshahi, A., Jakobiec, F. A., et al.: IgG4-related systemic disease as a cause of "idiopathic" orbital inflammation, including orbital myositis, and trigeminal nerve involvement. Surv. Ophthalmol., 2011, 57(1), 26-33.

[26] Berry-Brincat, A., Rose, G. E.: Idiopathic orbital inflammation: a new dimension with the discovery of immunoglobulin G4-related disease. Curr. Opin. Ophthalmol., 2012, 23(5), 415-419.

[27] Raess, P. W., Habashi, A., El Rassi, E., et al.: Overlapping morphologic and immunohistochemical features of Hashimoto thyroiditis and IgG4-related thyroid disease. Endocr. Pathol., 2015, $26(2), 170-177$.

(Nagy V. Endre dr., Debrecen, Nagyerdei krt. 98., 4012 e-mail: nagyendre@hotmail.com) 